\title{
Entrapment of the brachial artery following supracondylar fracture reduction
}

\author{
Dominic Charles Marshall, Joseph Shalhoub, Kaji Sritharan, Richard G Gibbs
}

Imperial College Health Care Trust, London, UK

\section{Correspondence to} Richard G Gibbs,

Richard.Gibbs@imperial.nhs.uk

Accepted 30 May 2015
CrossMark

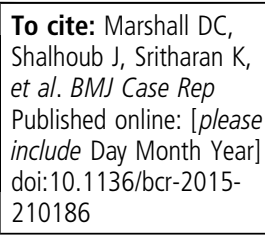

\section{DESCRIPTION}

A 4-year-old girl presented to the emergency department after falling from a climbing frame onto her left arm. She was diagnosed as having a supracondylar fracture clinically and radiologically. The fracture was treated with closed reduction and crossed K-wire fixation. Subsequent to the reduction clinical examination could not identify a palpable radial pulse. At that point she transferred to a tertiary vascular centre. On arrival, repeat neurovascular examination demonstrated an anterior interosseous nerve palsy, a non-palpable radial pulse and a capillary refill time of less than $2 \mathrm{~s}$ in the digits of the left hand. Doppler assessment identified a weak monophasic ulnar signal and an absent radial signal. Duplex ultrasound showed an abrupt termination of arterial flow within the left antecubital fossa. She proceeded to CT angiography, which appeared to demonstrate a transection
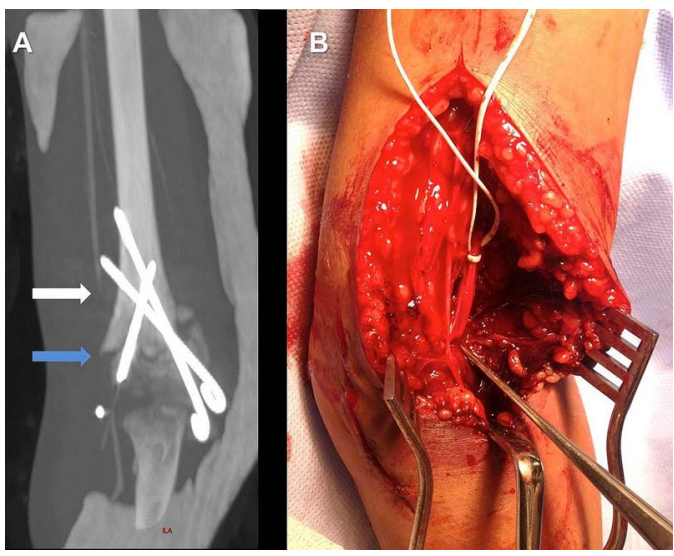

Figure 1 (A) Sagittal reconstruction of left upper limb CT angiogram showing termination of contrast opacification of the brachial artery (white arrow) proximal to the humeral supracondylar fracture site (blue arrow). (B) Intraoperative photograph demonstrating the distal left brachial artery diving into the humeral fracture site, under tension (indicated by the tip of the forceps). of the brachial artery in the antecubital fossa (figure 1A).

She underwent open exploration of the distal brachial artery in the antecubital fossa which identified that the brachial artery was trapped within the fracture site (figure 1B). The crossed K-wires were removed, the fracture distracted and the artery released. A small defect in the brachial artery required repair with interrupted sutures. The procedure resulted in immediate restoration of the radial pulse. The fracture was then re-reduced and refixed with K-wires under direct visualisation and fluoroscopic control. She made a good postoperative recovery and follow-up duplex assessment confirmed restoration of biphasic flow in the radial and ulnar arteries.

\section{Learning points}

- Reduction of a supracondylar fracture can cause entrapment of the brachial artery within the fracture site; this can have occurred in the context of a pink and pulseless limb.

- The clinical and imaging findings in this case mimic those of arterial transection.

- A thorough neurovascular assessment must be conducted both prior to and following any fracture reduction.

Contributors JS, RGG and KS diagnosed and managed the patient mentioned in the case. DCM and JS wrote the case manuscript and learning points. KS was the attending consultant when the patient presented to the emergency department. RGG and $\mathrm{KS}$ reviewed the manuscript, made the necessary corrections and offered suggestions for learning points.

Competing interests None declared.

Patient consent Obtained.

Provenance and peer review Not commissioned; externally pee reviewed.

Copyright 2015 BMJ Publishing Group. All rights reserved. For permission to reuse any of this content visit http://group.bmj.com/group/rights-licensing/permissions.

BMJ Case Report Fellows may re-use this article for personal use and teaching without any further permission.

Become a Fellow of BMJ Case Reports today and you can:

- Submit as many cases as you like

- Enjoy fast sympathetic peer review and rapid publication of accepted articles

- Access all the published articles

- Re-use any of the published material for personal use and teaching without further permission

For information on Institutional Fellowships contact consortiasales@bmjgroup.com

Visit casereports.bmj.com for more articles like this and to become a Fellow 